Jurnal Keperawatan Silampari

Volume 5, Nomor 1, Desember 2021

e-ISSN: 2581-1975

p-ISSN: 2597-7482

DOI: https://doi.org/10.31539/jks.v5i1.2969

IDMEKpE

\title{
METODE PEER EDUCATION TERHADAP PENGETAHUAN DAN DUKUNGAN KELUARGA PASIEN STROKE PADA MASA PANDEMI COVID-19
}

\author{
Selamat Parmin ${ }^{1}$, Mustikasari², Rohman Azzam ${ }^{3}$ \\ Universitas Kader Bangsa Palembang ${ }^{1}$ \\ Universitas Muhammadiyah Jakarta ${ }^{2,3}$ \\ Selamatparmin@gmail.com ${ }^{1}$
}

\begin{abstract}
ABSTRAK
Penelitian ini bertujuan untuk mengetahui pengaruh pendidikan kesehatan metode peer education terhadap pengetahuan dan dukungan keluarga pasien stroke pada masa pandemi COVID-19. Metode penelitian ini adalah penelitian kuantitatif dengan rancangan non equivalent control group design. Hasil penelitian menunjukkan bahwa sebagian besar responden pada kelompok intervensi memiliki pengetahuan baik sebanyak 78,0\%, dukungan keluarga tinggi sebanyak 64,0\% dan sebagian besar responden pada kelompok control memiliki pengetahuan kurang sebanyak 54,0\%, dukungan keluarga rendah sebanyak $60,0 \%$. Sesudah diberikan pendidikan: metode peer education pengetahuan baik sebanyak 76,5\% dengan $\rho$-value $=0,015$, dukungan keluarga sebanyak $64,7 \%$ dan $\rho$ value 0,009 , umur berhubungan dengan pengetahuan dan dukungan keluarga $(\rho<\alpha)$ sedangkan Pendidikan, sumber informasi tidak ada hubungan dengan pengetahuan dan dukungan keluarga ( $\rho$ value $>0,05$ ). Simpulan, terdapat pengaruh pendidikan kesehatan: metode peer education terhadap pengetahuan, dukungan keluarga pasien stroke pada masa pandemi COVID 19 di Puskesmas Kota Palembang, serta terdapat perbedaan pengetahuan dan dukungan keluarga dimana kelompok intervensi memiliki pengetahuan dan dukungan keluarga lebih tinggi, hasil analisis chi square didapatkan bahwa tidak ada hubungan karakteristik antara tingkat pendidikan dengan pengetahuan, serta tidak ada hubungan karakteristik antara sumber informasi dengan pengetahuan di Puskesmas Merdeka Ariodillah Basuki Rahmat tahun 2021.
\end{abstract}

Kata Kunci: Dukungan Keluarga, Pandemic COVID-19, Peer Education, Pengetahuan, Stroke

\begin{abstract}
This study aims to determine the effect of health education using the peer education method on the knowledge and support of families of stroke patients during the COVID-19 pandemic. This research method is a quantitative study with a non-equivalent control group design. The results showed that most respondents in the intervention group had good knowledge and 78.0\%, high family support as much as $64.0 \%$, and most respondents in the control group had less understanding than $54.0 \%$, low family support as much as $60.0 \%$. After being given Education: peer education method good knowledge as much as $76.5 \%$ with -value $=0.015$, family support as much as $64.7 \%$ and -value 0.009 , age is related to understanding and family support $(\rho<)$ while Education, source information has no relationship with family knowledge and consent ( $\rho$ value $>0.05)$. In conclusion, there is an effect of health education: the peer education method on expertise,
\end{abstract}


family support for stroke patients during the covid 19 pandemic at the Palembang City Health Center, and there are differences in knowledge and family support where the intervention group has higher knowledge and family support, the results of Chi-Square analysis are obtained. There is no characteristic relationship between education level and expertise, and there is no expected relationship between information sources and knowledge at the Merdeka Ariodillah Basuki Rahmat Health Center in 2021.

Keywords: Family Support, Pandemic COVID-19, Peer Education, Knowledge, Stroke

\section{PENDAHULUAN}

Pandemic virus corona, yang disebabkan oleh Severe Acute Respiratory Syndrome Coronavirus-2 (SARS-CoV-2), mengakibatkan lebih dari 4 - 8 juta kasus yang dikonfirmasi di seluruh dunia dan lebih dari 300.000 kematian (Ellul et al., 2020). Studi retrospektif yang dilakukan di Union Hospital of Huazhong University of Science and Technology dari 219 pasien dengan SARS-CoV-2 yang dikonfirmasi, $11(5,0 \%)$ berkembang onset baru Cerebro Vascular Disease (CVD) setelah infeksi COVID-19, dimana dari $10(90,9 \%)$ didiagnosis stroke iskemik dan $1(9,1 \%)$ mengalami perdarahan intraserebral ( $\mathrm{Li}$ et al., 2020).

Prevalensi stroke di Indonesia tahun 2018 pada penduduk umur $\geq 15$ tahun sebesar 10,9\%, atau diperkirakan sebanyak 2.120 .360 orang. Sedangkan prevalensi angka kejadian penyakit stroke di Provinsi Sumatera Selatan tahun 2018 berjumlah sebanyak 22.013 orang (10\%), angka kejadian penyakit stroke di Kota Palembang sendiri bulan Agustus tahun 2020 sebanyak 601 orang (Dinas kesehatan Sumatera Selatan, 2020).

Berdasarkan data angka kejadian di atas dan penelitian terbaru yang didapatkan dari penelitian Iadecola et al., (2020) mengatakan stroke tidak jarang terjadi di antara pasien yang dirawat di rumah sakit dengan COVID-19, dengan tingkat yang dilaporkan berkisar antara $1 \%-3 \%$ pada pasien yang dirawat di rumah sakit dan hingga $6 \%$ pada pasien yang sakit kritis, 7 kali lipat lebih tinggi dibandingkan pasien yang dirawat inap dengan flu sesuai dengan tingkat keparahan penyakit (Mao et al., 2020 ; Merkler et al., 2020; Yaghi et al., 2020). Laporan kasus yang lain menggambarkan stroke emboli yang tidak biasa pada individu muda yang sehat dengan COVID-19, dalam beberapa kasus pasien umumnya individu yang lebih tua dan memiliki banyak komorbiditas vascular yang dapat memperberat keadaan (Oxley et al., 2020; Lodigiani et al., 2020).

Selain itu menurut Wang et al., (2020) menjelaskan bahwa pandemi COVID-19 tidak hanya berdampak langsung pada kesehatan, tetapi juga sangat berpengaruh dan juga mempengaruhi akses publik ke rumah sakit, yang dapat mencegah pasien yang mengalami stroke untuk menerima terapi rehabilitasi standar. Manifestasi neurologis COVID-19 dalam beberapa laporan dapat menyebabkan komplikasi neurologis pada pasien stroke. ACE2 berfungsi sebagai reseptor utama untuk masuknya virus SARS-CoV2 ke dalam sel manusia, jalur ACE2 angiotensin memainkan peran pelindung saraf pada pasien dengan stroke sebagai pencegahan. Reseptor ACE2 sangat penting dalam penularan virus, tetapi pasien tetap tidak dianjurkan untuk berhenti menggunakan ACE atau obat penghambat reseptor angiotensin yang penting untuk pengendalian hipertensi (Chang et al., 2020).

Hal sejalan juga didapatkan dalam penelitian kunjungan klinik rawat jalan ke rumah sakit tersier besar di Cina menurun secara dramatis jumlah kunjungan ke pelayanan poliklinik rawat jalan, layanan rawat inap pada semua penyakit neurologis sebesar $23,8 \%$ pada bulan Februari dan dalam empat bulan berikutnya kembali menjadi 65,8\%, 82,2\%, 
$64,7 \%, 78,5 \%$, dan $89,1 \%$, pada jumlah pasien stroke rawat inap turun dengan cepat sebesar 27,4\% pada bulan Februari dan kemudian pulih kembali dengan cepat menjadi $103,9 \%, 92,2 \%, 66,1 \%, 90,0 \%$, dan 100\% masing-masing pada bulan Maret, April, Mei, Juni, dan Juli, dibandingkan dengan periode sebelum COVID-19.

Untuk menghilangkan kekhawatiran bagi pasien stroke selama menjalani pengobatan pada masa pandemi sangat diperlukan pemberian pendidikan kesehatan dalam hal ini peer education dengan pendekatan terstruktur dari kegiatan menolong kelompok kecil warga yang jadi target aktivitas dengan pembelajaran yang terorganisir oleh pendidik yang terlatih dalam upaya memperbaiki permasalahan tersebut. Pendidikan sebaya adalah alat yang menjanjikan untuk mempromosikan kemanjuran diri bagi orangorang dengan sumber daya dan pendidikan terbatas. Pendidik sebaya tersedia secara luas, hemat biaya, sesuai budaya, dan dapat membantu mengatasi ketidakpercayaan komunitas medis.

Hasil penelitian yang dilakukan oleh Bakri et al., (2020) didapatkan uji statistik yang digunakan adalah uji wilcoxon untuk mengetahui pengaruh pendidikan kesehatan tentang perawatan pasien stroke di rumah terhadap tingkat pengetahuan keluarga dan diperoleh nilai $\mathrm{p}=0,000$, artinya ada pengaruh pendidikan kesehatan tentang perawatan pasien stroke di rumah terhadap tingkat pengetahuan keluarga. Berdasarkan hasil penelitian serta teori yang ada dapat dibuat kesimpulan bahwa responden memiliki keinginan dan minat besar untuk dapat mempelajari dan menerapkan metode perawatan pasien stroke ini.

Berdasarkan hal tersebut perlu dilakukan pendidikan kesehatan; metode peer education terhadap pengetahuan dan dukungan keluarga pada pasien stroke dalam pencegahan COVID-19. Pendidikan kesehatan; metode peer education penting dilakukan dalam hal ini untuk memberikan pemahaman dan menghilangkan kekhawatiran bagi keluarga ataupun pasien stroke, mencukupi semua yang dibutuhkan untuk pasien stroke mulai dari dukungan keluarga ataupun kebutuhan selama pemulihan pasien stroke saat menjalani pengobatan pada masa pandemi serta mencegah semakin memperburuknya keadaan pasien stroke diakibatkan oleh terpaparnya dengan COVID-19. Untuk itu peneliti tertarik meneliti tentang pengaruh pendidikan kesehatan; metode peer education terhadap pengetahuan dan dukungan keluarga pasien stroke pada masa pandemi COVID-19 di Puskesmas.

Penelitian yang dilakukan oleh Komalasari (2019); Kosasih et al., (2018) menunjukan bahwa edukasi kesehatan terbukti berpengaruh dalam meningkatkan tingkat pengetahuan pasien dan keluarganya mengenai stroke, kesiapan pasien stroke, peran keluarga pengasuh pasien stroke, dukungan psikologis yang diperlukan pasien stroke, dan persiapan perawatan pasien stroke di rumah. Edukasi Kesehatan tidak berpengaruh terhadap tingkat kesiapan pasien stroke untuk transisi. Kesiapan untuk menerima transisi pada pasien stroke tidak cukup dengan edukasi kesehatan saja tapi diperlukan peran serta keluarga dalam memberikan dukungan kepada pasien tersebut, oleh karena itu disarankan agar perawat selalu mensupport keluarga agar melakukan dukungan pada pasien stroke.

Sudah ada beberapa penelitian yang mengkaji tentang pendidikan kesehatan; peer education, namun masing-masing daerah tentu memiliki karakteristik tersendiri terkait tema tersebut. Baik dari penyebab perubahan pengetahuan dan dukungan keluarga, siapa saja yang terlibat, tahapan yang dilalui selama pendidikan kesehatan; peer education, hambatan yang dilalui dan kewenangan masing-masing pihak yang terlibat. Selain itu, fokus masalah yang dikaji yakni terkait dengan pengaruh pendidikan kesehatan; metode 
peer education terhadap pengetahuan dan dukungan keluarga pada masa pandemi COVID 19 dalam sebuah forum belum banyak dilakukan oleh peneliti terdahulu.

\section{METODE PENELITIAN}

Penelitian kuantitatif dengan rancangan yang digunakan yaitu non equivalent control group design. Desain penelitian ini quasi experiment with control group design. Variabel yang diteliti yaitu variabel dependen (pengetahuan dan dukungan keluarga) dan variable independent (pendidikan: metode peer education), variabel confounding (usia, pendidikan, dan sumber informasi). Populasi pada penelitian ini adalah keluarga pasien stroke yang berobat ke puskesmas kota Palembang berjumlah 50 responden untuk kelompok intervensi dan 50 responden untuk kelompok control dengan metode pengambilan sampel purposive sampling. Tempat penelitian dilakukan penelitian adalah UPTD Puskemas Merdeka, Ariodillah dan Basuki Rahmat.

\section{HASIL PENELITIAN}

Tabel. 1

Analisis Kesetaraan Berdasarkan Pendidikan, Sumber Informasi Keluarga Pasien Tahun 2021 ( N = 100)

\begin{tabular}{lccccccc}
\hline \multirow{2}{*}{ Karakteristik } & \multicolumn{2}{c}{$\begin{array}{c}\text { Kelompok } \\
\text { Intervensi (N=50) }\end{array}$} & \multicolumn{2}{c}{$\begin{array}{c}\text { Kelompok } \\
\text { kontrol (N=50) }\end{array}$} & Total (N=100) & \multirow{2}{*}{$\begin{array}{c}\mathrm{P} \\
\text { value }\end{array}$} \\
\cline { 2 - 6 } & $\mathrm{N}$ & $\%$ & $\mathrm{~N}$ & $\%$ & $\mathrm{~N}$ & $\%$ & \\
\hline Pendidikan & 2 & 4,0 & 4 & 8,0 & 6 & 12,0 & \\
- SD & 20 & 40,0 & 25 & 50,0 & 45 & 90,0 & 0,161 \\
- SMP & 22 & 44,0 & 21 & 42,0 & 43 & 82,0 & \\
- SMA & 6 & 12,0 & - & - & 6 & 12,0 & \\
- Perguruan tinggi & & & & & & & \\
\hline Sumber informasi & 44 & 88,0 & 36 & 72,0 & 80 & 80 & 0,167 \\
- Tidak bervariasi & 6 & 12,0 & 14 & 28,0 & 20 & 20 & \\
- Bervariasi & & & & & & & \\
\hline
\end{tabular}

Berdasarkan tabel 1 menunjukkan bahwa responden pada kelompok intervensi memiliki pendidikan SMA sebanyak 44,0\% dan sebagian besar responden pada kelompok kontrol memiliki pendidikan SMP sebanyak 50,0\%. Sebagian besar responden kelompok intervensi dan kelompok kontrol memiliki sumber informasi tidak bervariasi dengan masing-masing sebanyak $88,0 \%$ dan $72,0 \%$.

\section{Pengetahuan}

Tabel. 2

Analisis Kesetaraan Berdasarkan Pengetahuan Keluarga Pasien Stroke Tahun $2021(\mathrm{~N}=100)$

\begin{tabular}{lccccccc}
\hline \multirow{2}{*}{ Karakteristik } & \multicolumn{2}{c}{ Kelompok } & \multicolumn{2}{c}{ Kelompok } & Total (N=100) & \multirow{2}{*}{$\begin{array}{c}\mathrm{P} \\
\text { Intervensi }(\mathrm{N}=50)\end{array}$} & \multicolumn{2}{c}{ kontrol $(\mathrm{N}=50)$} & & & value \\
\cline { 2 - 6 } & $\mathrm{N}$ & $\%$ & $\mathrm{~N}$ & $\%$ & $\mathrm{~N}$ & $\%$ & \\
\hline Pengetahuan & 39 & 78,0 & 19 & 38,0 & 58 & 100 & 0,015 \\
- baik & 2 & 4,0 & 4 & 8,0 & 6 & 100 & \\
- cukup & 9 & 18,0 & 27 & 54,0 & 36 & 100 & \\
- kurang & & & & & & & \\
\hline
\end{tabular}


Berdasarkan tabel 2 menunjukkan bahwa sebagian besar responden pada kelompok intervensi memiliki pengetahuan baik sebanyak 78,0\% dan sebagian besar responden pada kelompok control memiliki pengetahuan kurang sebanyak 54,0\%.

\section{Dukungan Keluarga}

Tabel. 3

Analisis Kesetaraan Berdasarkan Dukungan Keluarga

Pasien Stroke Tahun $2021(\mathrm{~N}=100)$

\begin{tabular}{|c|c|c|c|c|c|c|c|}
\hline \multirow[t]{2}{*}{ Karakteristik } & \multicolumn{2}{|c|}{$\begin{array}{c}\text { Kelompok } \\
\text { Intervensi }(\mathrm{N}=50)\end{array}$} & \multicolumn{2}{|c|}{$\begin{array}{l}\text { Kelompok kontrol } \\
(\mathrm{N}=50)\end{array}$} & \multicolumn{2}{|c|}{$\begin{array}{c}\text { Total } \\
(\mathrm{N}=100)\end{array}$} & \multirow[t]{2}{*}{$\begin{array}{c}\mathrm{P} \\
\text { value } \\
\end{array}$} \\
\hline & $\mathrm{N}$ & $\%$ & $\mathrm{~N}$ & $\%$ & $\mathrm{~N}$ & $\%$ & \\
\hline \multicolumn{8}{|c|}{ Dukungan Keluarga } \\
\hline - Tinggi & 32 & 64,0 & 15 & 30,0 & 47 & 100 & \\
\hline - Sedang & 1 & 2,0 & 5 & 10,0 & 6 & 100 & 0,009 \\
\hline - Rendah & 7 & 34,0 & 30 & 60,0 & 37 & 100 & \\
\hline
\end{tabular}

Berdasarkan tabel 3 menunjukkan bahwa sebagian besar responden pada kelompok intervensi memperlihatkan dukungan keluarga tinggi sebanyak 64,0\% dan sebagian besar responden pada kelompok control memperlihatkan dukungan keluarga rendah sebanyak $60,0 \%$.

\section{Perubahan Pengetahuan dan Dukungan Keluarga Sebelum dan Sesudah Pemberian Pendidikan: Metode Peer Education COVID-19}

Tabel. 4

Analisis Perubahan Pengetahuan dan Dukungan Keluarga Pasien Stroke Sebelum dan Sesudah Pemberian Pendidikan; Metode Peer Education COVID-19 $(\mathrm{N}=50)$

\begin{tabular}{|c|c|c|c|c|c|c|c|c|c|c|}
\hline \multirow[t]{3}{*}{ Karakteristik } & \multicolumn{4}{|c|}{$\begin{array}{l}\text { Kelompok intervensi } \\
(\mathrm{N}=50)\end{array}$} & \multirow[t]{3}{*}{$\begin{array}{c}\mathrm{P} \\
\text { value }\end{array}$} & \multicolumn{4}{|c|}{$\begin{array}{l}\text { Kelompok control } \\
(\mathrm{N}=50)\end{array}$} & \multirow[t]{3}{*}{$\begin{array}{c}\mathrm{P} \\
\text { value }\end{array}$} \\
\hline & \multicolumn{2}{|c|}{$\begin{array}{l}\text { Pretest } \\
(\mathrm{N}=50)\end{array}$} & \multicolumn{2}{|c|}{$\begin{array}{l}\text { Posttest } \\
(\mathrm{N}=50)\end{array}$} & & \multicolumn{2}{|c|}{$\begin{array}{l}\text { Pretest } \\
(\mathrm{N}=50)\end{array}$} & \multicolumn{2}{|c|}{$\begin{array}{l}\text { Posttest } \\
(\mathrm{N}=50)\end{array}$} & \\
\hline & $\mathrm{N}$ & $\%$ & $\mathrm{~N}$ & $\%$ & & $\mathrm{~N}$ & $\%$ & $\mathrm{~N}$ & $\%$ & \\
\hline \multicolumn{11}{|l|}{ Pengetahuan } \\
\hline - Baik & 31 & 60,8 & 39 & 76,5 & 0,000 & 20 & 40,0 & 19 & 38,0 & 027 \\
\hline - Cukup & 2 & 3,9 & 2 & 3,9 & & 4 & 8,0 & 4 & 8,0 & 0,247 \\
\hline - Kurang & 18 & 35,3 & 10 & 19,6 & & 26 & 52,0 & 27 & 54,0 & \\
\hline
\end{tabular}

Berdasarkan tabel 4 menunjukkan bahwa pada kelompok intervensi terdapat peningkatan pengetahuan sebelum dan sesudah diberikan metode peer education dari 60,8\% menjadi 76,5\% dengan kategori baik. Sedangkan pada variabel dukungan keluarga juga terjadi peningkatan dari 52,9\% menjadi 64,7\% dengan kategori tinggi. Hasil analisis menunjukkan $\rho$-value pengetahuan dan dukungan keluarga $=0,000$, sehingga terdapat perubahan pengetahuan sebelum dan sesudah pemberian pendidikan; peer education.

Sebagian besar responden pada kelompok kontrol sebelum diberikan pendidikan; metode peer education memberikan pengetahuan baik sebanyak $40 \%$ dan sebagian besar responden sesudah diberikan pendidikan; metode peer education memperlihatkan pengetahuan baik sebanyak $38 \%$ dengan $\rho$ value pengetahuan dan dukungan keluarga $=0,247$, dengan nilai $\alpha=0,05(\rho>\alpha)$ maka dapat disimpulkan tidak terdapat perubahan 
pengetahuan. Sebagian besar responden kelompok kontrol sebelum diberikan pendidikan; metode peer education memperlihatkan dukungan keluarga tinggi sebanyak 30,0\% dan sebagian besar responden pada sesudah diberikan pendidikan; metode peer education memperlihatkan dukungan keluarga tinggi sebanyak 64,0\% dengan $\rho$ value pengetahuan dan dukungan keluarga $=0,894$, dengan nilai $\alpha=0,05(\rho>\alpha)$ maka dapat disimpulkan tidak terdapat perubahan dukungan keluarga pada kelompok kontrol.

\section{Perbedaan Pengetahuan dan Dukungan Keluarga pada Kelompok Intervensi dan Kelompok Kontrol}

Tabel. 5

Perbedaan Pengetahuan dan Dukungan Keluarga Pasien Stroke pada Kelompok Intervensi dan Kelompok Kontrol dalam Pencegahan COVID 19 ( $\mathrm{N}=100)$

\begin{tabular}{|c|c|c|c|c|c|c|}
\hline \multirow[t]{2}{*}{ No } & \multirow[t]{2}{*}{ Karakteristik } & \multicolumn{2}{|c|}{$\begin{array}{l}\text { Kelompok } \\
\text { Intervensi } \\
(\mathrm{N}=50)\end{array}$} & \multicolumn{2}{|c|}{$\begin{array}{c}\text { Kelompok } \\
\text { kontrol } \\
(\mathrm{N}=50)\end{array}$} & \multirow[t]{2}{*}{$\rho$ value } \\
\hline & & $\mathrm{N}$ & $\%$ & $\mathrm{~N}$ & $\%$ & \\
\hline 1 & $\begin{array}{l}\text { Pengetahuan } \\
\text { - Baik } \\
\text { - Cukup } \\
\text { - Kurang } \\
\end{array}$ & $\begin{array}{c}39 \\
2 \\
10 \\
\end{array}$ & $\begin{array}{c}76,5 \\
3,9 \\
19,6 \\
\end{array}$ & $\begin{array}{c}19 \\
4 \\
27 \\
\end{array}$ & $\begin{array}{c}38,0 \\
8,0 \\
54,0 \\
\end{array}$ & 0,000 \\
\hline 2 & $\begin{array}{cc}\text { Dukungan Keluarga } \\
\text { - } & \text { Tinggi } \\
- & \text { Sedang } \\
- & \text { Rendah }\end{array}$ & $\begin{array}{c}33 \\
1 \\
7\end{array}$ & $\begin{array}{c}64,7 \\
2,0 \\
33,3\end{array}$ & $\begin{array}{c}15 \\
5 \\
30\end{array}$ & $\begin{array}{l}30,0 \\
10,0 \\
60,0\end{array}$ & 0,000 \\
\hline
\end{tabular}

Berdasarkan tabel 5 menunjukkan bahwa sebagian besar responden pada kelompok intervensi memperlihatkan pengetahuan baik sebanyak $76,5 \%$ dan sebagian besar responden pada kelompok kontrol memperlihatkan pengetahuan kurang sebanyak 54,0\%. Sebagian besar responden pada kelompok intervensi memiliki dukungan keluarga tinggi sebanyak $64,7 \%$ dan sebagian besar responden pada kelompok kontrol dukungan keluarga rendah sebanyak 60,0\%, dengan pengetahuan dan dukungan keluarga $\rho$ value $=$ 0,000 , sehingga terdapat perbedaan pengetahuan dan dukungan keluarga sesudah pemberian pendidikan; metode peer education pada pasien stroke dalam pencegahan COVID 19 di Puskesmas pada kelompok intervensi.

Hubungan Karakteristik Pengetahuan dan Dukungan Keluarga dengan Pemberian Pendidikan Kesehatan; Metode Peer Education pada Kelompok Intervensi dan Kelompok Kontrol

Tabel. 6

Hubungan Umur dengan Pengetahuan dan Dukungan Keluarga

\begin{tabular}{lcc}
\hline \multicolumn{1}{c}{ Umur dengan Pengetahuan } & $\begin{array}{c}\text { Rata-Rata } \pm \text { Standar } \\
\text { Deviasi }\end{array}$ & $\rho$ value \\
\hline Kelompok Control & $55,18 \pm 7,10$ & 0,000 \\
Kelompok Intervensi & $56,44 \pm 7,65$ & 0,000 \\
\hline Umur dengan Dukungan Keluarga & & \\
\hline Kelompok Control & $52,88 \pm 6,94$ & 0,000 \\
Kelompok Intervensi & $54,74 \pm 8,05$ & 0,000 \\
\hline
\end{tabular}


Berdasarkan tabel 6 didapatkan $\rho$-value $=0,000$ kelompok control dan kelompok intervensi, berarti ada hubungan umur dengan pengetahuan dan dukungan keluarga di Puskesmas Palembang tahun 2021.

Tabel. 7

Hubungan Pendidikan Keluarga Pasien Stroke

dengan Pengetahuan Keluarga Pasien Stroke Tahun 2021

\begin{tabular}{|c|c|c|c|c|c|c|c|c|c|c|}
\hline \multirow{3}{*}{ No } & \multirow{3}{*}{ Pendidikan } & \multicolumn{6}{|c|}{ Pengetahuan } & \multirow{2}{*}{\multicolumn{2}{|c|}{ Jumlah }} & \multirow{3}{*}{$\begin{array}{c}\rho \\
\text { value } \\
\end{array}$} \\
\hline & & \multicolumn{2}{|c|}{ Baik } & \multicolumn{2}{|c|}{ Cukup } & \multicolumn{2}{|c|}{ Kurang } & & & \\
\hline & & $\mathrm{n}$ & $\%$ & $\mathrm{n}$ & $\%$ & $\mathrm{n}$ & $\%$ & $\mathrm{n}$ & $\%$ & \\
\hline 1. & $\mathrm{SD}$ & 3 & 75,0 & 0 & 0 & 1 & 25,0 & 4 & 100 & \multirow{4}{*}{0,346} \\
\hline 2. & SMP & 10 & 40,0 & 3 & 12,0 & 12 & 48,0 & 25 & 100 & \\
\hline 3. & SMA & 6 & 28,6 & 1 & 4,8 & 14 & 66,7 & 21 & 100 & \\
\hline & Jumlah & 19 & 38,0 & 4 & 8,0 & 27 & 54,0 & 50 & 100 & \\
\hline
\end{tabular}

Berdasarkan tabel 7 didapatkan responden yang memiliki pengetahuan baik dan memiliki tingkat pendidikan SMP sebanyak 10 responden $(40,0) \%$, lebih banyak jika dibandingkan responden yang memiliki pengetahuan baik, memiliki tingkat pendidikan SD sebanyak 3 responden $(75,0 \%)$ dan responden yang memiliki pengetahuan baik dan memiliki tingkat pendidikan SMA 6 responden $(28,6 \%)$. Berdasarkan uji statistik didapatkan $\rho$ value $=0,346$, sehingga tidak ada hubungan tingkat pendidikan dengan pengetahuan di Puskesmas Palembang Tahun 2021.

Tabel. 8

Hubungan Pendidikan Keluarga Pasien Stroke dengan Dukungan Keluarga di Puskesmas Palembang Tahun 2021

\begin{tabular}{|c|c|c|c|c|c|c|c|c|c|c|}
\hline \multirow{3}{*}{ No } & \multirow{3}{*}{ Pendidikan } & \multicolumn{6}{|c|}{ Dukungan Keluarga } & \multirow{2}{*}{\multicolumn{2}{|c|}{ Jumlah }} & \multirow{3}{*}{$\rho$ value } \\
\hline & & \multicolumn{2}{|c|}{ Tinggi } & \multicolumn{2}{|c|}{ Sedang } & \multicolumn{2}{|c|}{ Rendah } & & & \\
\hline & & $\mathrm{n}$ & $\%$ & $\mathrm{n}$ & $\%$ & $\mathrm{n}$ & $\%$ & $\mathrm{n}$ & $\%$ & \\
\hline 1. & SD & 2 & 50,0 & 0 & 0 & 2 & 50,0 & 4 & 100 & \multirow{4}{*}{0,601} \\
\hline 2. & SMP & 7 & 28,0 & 4 & 16,0 & 14 & 56,0 & 25 & 100 & \\
\hline \multirow[t]{2}{*}{3.} & SMA & 6 & 28,6 & 1 & 4,8 & 14 & 66,7 & 21 & 100 & \\
\hline & Jumlah & 15 & 30,0 & 5 & 10,0 & 30 & 60,0 & 50 & 100 & \\
\hline
\end{tabular}

Pada tabel 8 didapatkan responden yang memiliki dukungan keluarga tinggi dan memiliki tingkat pendidikan SMP sebanyak 7 responden $(28,0) \%$ dan responden yang memiliki dukungan keluarga tinggi yang memiliki tingkat pendidikan SMA sebanyak 6 responden $(28,6 \%)$. Berdasarkan hasil uji statistik dengan analisis chi square didapatkan $\rho$ value $=0,601$, sehingga tidak ada hubungan antara tingkat pendidikan dengan dukungan keluarga di Puskesmas Palembang tahun 2021.

Tabel. 9

Hubungan Sumber Informasi dengan Pengetahuan

\begin{tabular}{|c|c|c|c|c|c|c|c|c|c|c|}
\hline \multirow{3}{*}{ No } & \multirow{3}{*}{$\begin{array}{l}\text { Sumber } \\
\text { Informasi }\end{array}$} & \multicolumn{6}{|c|}{ Pengetahuan } & \multirow{2}{*}{\multicolumn{2}{|c|}{ Jumlah }} & \multirow{3}{*}{$\begin{array}{c}\rho \\
\text { value }\end{array}$} \\
\hline & & \multicolumn{2}{|c|}{ Baik } & \multicolumn{2}{|c|}{ Cukup } & \multicolumn{2}{|c|}{ Kurang } & & & \\
\hline & & $\mathrm{n}$ & $\%$ & $\mathrm{n}$ & $\%$ & $\mathrm{n}$ & $\%$ & $\mathrm{n}$ & $\%$ & \\
\hline 1. & Bervariasi & 6 & 50,0 & 0 & 0 & 8 & 50,0 & 14 & 100 & \\
\hline \multirow[t]{2}{*}{2.} & $\begin{array}{l}\text { Tidak } \\
\text { Bervariasi }\end{array}$ & 13 & 28,0 & 4 & 16,0 & 19 & 56,0 & 36 & 100 & 0,425 \\
\hline & Jumlah & 19 & 38,0 & 4 & 8,0 & 27 & 54,0 & 50 & 100 & \\
\hline
\end{tabular}


Pada tabel 9 didapatkan responden yang memiliki pengetahuan baik dan memiliki sumber informasi tidak bervariasi sebanyak 13 responden $(28,0) \%$, lebih banyak jika dibandingkan dengan responden yang memiliki pengetahuan baik dan memiliki sumber informasi bervariasi sebanyak 6 responden $(50,0 \%)$. Berdasarkan hasil uji statistik dengan analisis chi square didapatkan $\rho$ value $=0,425$ lebih besar dari $\alpha=0,05$ menunjukkan bahwa tidak ada hubungan antara sumber informasi dengan pengetahuan di Puskesmas Palembang tahun 2021.

Tabel. 10

Hubungan Sumber Informasi

dengan Dukungan Keluarga

\begin{tabular}{|c|c|c|c|c|c|c|c|c|c|c|}
\hline \multirow{3}{*}{ No } & \multirow{3}{*}{$\begin{array}{l}\text { Sumber } \\
\text { Informasi }\end{array}$} & \multicolumn{6}{|c|}{ Dukungan Keluarga } & \multirow{2}{*}{\multicolumn{2}{|c|}{ Jumlah }} & \multirow{3}{*}{$\begin{array}{c}\rho \\
\text { value }\end{array}$} \\
\hline & & \multicolumn{2}{|c|}{ Tinggi } & \multicolumn{2}{|c|}{ Sedang } & \multicolumn{2}{|c|}{ Rendah } & & & \\
\hline & & $\mathrm{n}$ & $\%$ & $\mathrm{n}$ & $\%$ & $\mathrm{n}$ & $\%$ & $\mathrm{~N}$ & $\%$ & \\
\hline 1. & Bervariasi & 5 & 35,7 & 0 & 0 & 9 & 64,3 & 14 & 100 & \\
\hline 2. & $\begin{array}{l}\text { Tidak } \\
\text { Bervariasi }\end{array}$ & 10 & 27,8 & 5 & 13,9 & 21 & 58,3 & 36 & 100 & 0,330 \\
\hline & jumlah & 15 & 30,0 & 5 & 10,0 & 30 & 60,0 & 50 & 100 & \\
\hline
\end{tabular}

Pada tabel 10 didapatkan responden yang memiliki dukungan keluarga tinggi dan memiliki sumber informasi tidak bervariasi sebanyak 10 responden $(27,8 \%)$, lebih banyak jika dibandingkan dengan responden yang memiliki dukungan keluarga tinggi dan memiliki sumber informasi bervariasi sebanyak 5 responden (35,7\%). Berdasarkan hasil uji statistik didapatkan $\rho$ value $=0,330$ lebih besar dari $\alpha=0,05$ menunjukkan bahwa tidak ada hubungan antara sumber informasi dengan memiliki dukungan keluarga di Puskesmas Palembang Tahun 2021.

\section{PEMBAHASAN}

\section{Karakteristik}

Berdasarkan hasil penelitian diketahui bahwa rata-rata umur pada kelompok intervensi sebesar 54,44, umur pada kelompok intervensi terendah adalah 45 dan skor tertinggi adalah 68. Rata-rata umur pada kelompok kontrol sebesar 55,18, umur pada kelompok kontrol terendah adalah 45 dan skor tertinggi adalah 68. Usia tersebut merupakan usia dewasa pertengahan dimana merupakan usia produktif bagi seseorang. Pada usia produktif seseorang cenderung untuk bekerja lebih keras sehingga kemungkinan untuk mendapatkan stress kerja sangat tinggi.

Dari hasil penelitian dan penelitian terkait dapat disimpulkan bahwa rata-rata usia keluarga pendamping pasien stroke sangat beragam mulai dari $40 \mathrm{~s} / \mathrm{d} 68$ tahun yang merupakan kelompok usia pertengahan (middle age) sampai dengan kelompok usia lansia muda (young old) yang masih aktif untuk menemani anggota keluarga dalam melakukan pengobatan.

Berdasarkan hasil penelitian diketahui bahwa sebagian besar responden pada kelompok intervensi memiliki pendidikan SMA dan sebagian besar responden pada kelompok kontrol memiliki pendidikan SMP. Berdasarkan asumsi peneliti tingkat pendidikan yang lebih tinggi akan memudahkan seseorang atau masyarakat untuk menyerap informasi dan mengimplementasikan dalam perilaku sehari-hari, khususnya dalam hal kesehatan, tingkat pendidikan formal membentuk nilai bagi seseorang terutama dalam menerima hal baru. 
Dari hasil penelitian dapat disimpulkan bahwa ada perbedaan antara hasil peneliti mengenai tingkat pendidikan yang didapat dilapangan dengan hasil penelitian terkait, berdasarkan temuan peneliti didapatkan pendidikan terbanyak di tingkat SMA dan SMP sedangkan hasil penelitian terkait didapatkan pendidikan terbanyak yaitu pada tingkat perguruan tinggi.

Berdasarkan hasil penelitian diketahui bahwa sebagian besar responden pada kelompok intervensi memiliki sumber informasi tidak bervariasi. Sumber informasi baik media cetak, elektronik (TV, radio, internet, dan sebagainya), maupun media lainnya yang dapat memberikan informasi terkait penyakit stroke, sehingga responden dapat mengakses dengan mudah hal-hal yang belum mereka ketahui. Akibatnya responden memiliki tingkat pengetahuan yang baik tentang penyakit stroke.

Penelitian yang dilakukan didapatkan hasil sebagian besar responden mendapat informasi tentang stroke melalui media elektronik yaitu sebanyak 55 orang (55\%), melalui media cetak ada sebanyak 10 orang $(10 \%)$, melalui teman atau saudara sebanyak 34 orang (34\%), dan 1 orang (1\%) menyebutkan sumber lainnya yaitu perkuliahan.

Dari hasil penelitian dan penelitian terkait dapat disimpulkan bahwa sumber informasi yang terbanyak digunakan oleh keluarga pasien stroke tidak bervariasi sejalan dengan penelitian terkait yang didapatkan data bahwa mendapat sumber informasi terbanyak melalui media elektronik atau tidak bervariasi.

\section{Pengetahuan dan Dukungan Keluarga}

Berdasarkan hasil penelitian diketahui bahwa sebagian besar kelompok intervensi memiliki pengetahuan baik dibandingkan kelompok kontrol memiliki pengetahuan kurang. Pengetahuan merupakan domain yang sangat penting dalam terbentuknya perilaku masyarakat, pengetahuan yang baik terhadap suatu penyakit tertentu akan memberikan pengaruh untuk melakukan tindakan pencegahan penularan penyakit tersebut kepada orang-orang yang berada di sekitarnya.

Penelitian yang dilakukan oleh Ayuni et al., (2021) didapatkan hasil hampir seluruh responden dapat menjawab dengan benar setiap item pertanyaan tentang stroke, dengan frekuensi jawaban benar tertinggi adalah pertanyaan ketiga dan kelima tentang gejala dan komplikasi stroke yaitu sebanyak 97 orang (97\%), sedangkan frekuensi jawaban benar terendah adalah pertanyaan kedelapan tentang usia meningkatnya risiko stroke yaitu sebanyak 21 orang $(21 \%)$.

Berdasarkan hasil penelitian diketahui bahwa sebagian besar kelompok intervensi memiliki dukungan keluarga tinggi dan pada kelompok kontrol memiliki dukungan keluarga rendah. Orang yang berada dalam lingkungan sosial yang suportif umumnya memiliki kondisi yang lebih baik dibandingkan rekannya yang tanpa keuntungan ini, karena dukungan keluarga dianggap dapat mengurangi atau menyangga efek kesehatan mental individu.

\section{Perubahan Pengetahuan dan Dukungan Keluarga Sebelum dan Sesudah Pemberian Pendidikan; Metode Peer Education COVID-19}

Hasil penelitian yang dilakukan didapatkan hasil sebagian besar responden pada kelompok intervensi sebelum diberikan pendidikan; metode peer education memiliki pengetahuan cukup baik dan sesudah diberikan pendidikan; metode peer education memiliki pengetahuan sangat baik dengan nilai $\rho$ value $=0,000$, dengan nilai $\alpha=0,05$ ( $\rho<$ $\alpha$ ), serta sebelum dan sesudah dilakukan pendidikan kesehatan; metode peer education didapatkan hasil sebagian besar responden pada kelompok intervensi memperlihatkan 
dukungan keluarga yang tinggi dan setelah diberikan pendidikan; metode peer education memperlihatkan dukungan keluarga yang sangat tinggi, maka dapat disimpulkan bahwa terdapat perubahan pengetahuan dan dukungan keluarga sebelum dan sesudah pemberian pendidikan; metode peer education COVID-19 Puskesmas Kota Palembang.

Hasil penelitian sejalan dengan penelitian yang dilakukan oleh Bakri et al., (2020) didapatkan uji statistik yang digunakan adalah uji wilcoxon untuk mengetahui pengaruh pendidikan kesehatan tentang perawatan pasien stroke di rumah terhadap tingkat pengetahuan keluarga dan diperoleh nilai $\mathrm{p}=0,000$, artinya ada pengaruh pendidikan kesehatan tentang perawatan pasien stroke di rumah terhadap tingkat pengetahuan keluarga. Berdasarkan hasil penelitian serta teori yang ada dapat dibuat kesimpulan bahwa responden memiliki keinginan dan minat besar untuk dapat mempelajari dan menerapkan metode perawatan pasien stroke ini. Mereka akan lebih senang jika dapat melakukan perawatan pada keluarga yang stroke secara mandiri di rumah masing selama masa pandemi COVID 19. Hal ini selain lebih santai, mereka juga dapat mengurangi pengeluaran biaya perawatan di rumah sakit. Menurut peneliti hal ini sejalan dengan data bahwa sebagian besar mereka adalah ibu rumah tangga dengan penghasilan yang mungkin hanya cukup untuk memenuhi kebutuhan hidup sehari-hari. Hal ini yang mendorong mereka menyimak dengan baik pendidikan kesehatan yang diberikan oleh tim peneliti saat penelitian ini berlangsung.

\section{Perbedaan Pengetahuan dan Dukungan Keluarga pada Kelompok Intervensi dan Kelompok Kontrol}

Hasil penelitian yang dilakukan didapatkan pada kelompok intervensi memiliki pengetahuan baik dan pada kelompok kontrol memiliki pengetahuan kurang dengan $\rho$ value $=0,000$. Pada kelompok intervensi memiliki dukungan keluarga tinggi dan pada kelompok kontrol memiliki dukungan keluarga rendah dengan $\rho$ value $=0,000$.

Menurut Zhao et al., (2020); Pustikasari \& Restiana (2019) dukungan keluarga adalah suatu bentuk perilaku melayani yang dilakukan oleh keluarga baik dalam bentuk dukungan emosional, penghargaan/penilaian, informasional dan instrumental. Strategi preventif yang paling baik untuk meningkatkan dukungan keluarga yang adekuat dalam membantu anggota keluarga dalam mempertahankan kesehatan. Keluarga yang baik akan memberi pengaruh positif bagi perkembangan lansia, dan sebaliknya.

Hasil penelitian sejalan dengan penelitian yang dilakukan oleh Hendayani \& Sari (2018) menunjukkan hasil uji-t dukungan keluarga pada pasien stroke sebelum dan sesudah dilaksanakan penyuluhan kesehatan didapatkan $p$-value $0,000(\alpha \leq 0,05)$ artinya, terdapat perbedaan yang signifikan antara dukungan keluarga yang diberikan pada pasien stroke sebelum dan sesudah dilakukan penyuluhan kesehatan. Hasil uji-t pada konsep diri pasien stroke sebelum dan sesudah didapatkan $p$-value $0,000(\alpha \leq 0,05)$ artinya, terdapat perbedaan yang signifikan antara konsep diri pasien stroke sebelum dan sesudah dilakukan penelitian. Sehingga dapat disimpulkan bahwa ada pengaruh dukungan keluarga terhadap konsep diri pasien stroke yang mengalami kelumpuhan di Poli Klinik Saraf Rumah Sakit Stroke Nasional Bukit Tinggi ditandai dengan $p$ value $=0,000(\alpha$ $\leq 0,05)$.

Berdasarkan hasil penelitian serta teori yang ada dapat dibuat kesimpulan bahwa pengalaman perubahan citra tubuh terhadap pasien stroke menyatakan bahwa tingkat ketergantungan yang tinggi terhadap keluarga dalam melakukan kegiatan sehari-hari membuat pasien stroke menganggap dukungan keluarga merupakan hal yang sangat 
dibutuhkan menuju kesembuhan. Perawatan yang telaten dan sikap positif keluarga berdampak besar bagi penderita.

\section{Hubungan Karakteristik dengan Pengetahuan dan Dukungan Keluarga Pemberian Pendidikan Kesehatan; Metode Peer Education pada Kelompok Intervensi dan Kelompok Kontrol}

Berdasarkan hasil penelitian menggunakan uji independent t test didapatkan $\rho$ value $=0,000$ pada kelompok kontrol dan kelompok intervensi, dengan nilai $\alpha=0,05(\rho<\alpha)$, berarti ada hubungan umur dengan pengetahuan dan dukungan keluarga di Puskesmas Palembang tahun 2021.

Berdasarkan hasil penelitian serta teori yang ada dapat dibuat kesimpulan bahwa semakin cukup umur, tingkat kematangan dan kekuatan seseorang akan lebih matang dalam berfikir serta kesiapan dalam menerima informasi yang baru untuk dapat diberikan kepada keluarga pasien stroke akan semakin maksimal baik dalam mengambil keputusan pada saat proses pengobatan maupun dalam memberikan dukungan kepada keluarga.

Berdasarkan hasil penelitian uji statistik dengan analisis chi square didapatkan $\rho$ value $=0,816$ lebih besar dari $\alpha=0,05$ menunjukkan bahwa tidak ada hubungan antara tingkat pendidikan dengan pengetahuan di Puskesmas Palembang tahun 2021.

Berdasarkan hasil penelitian serta teori yang ada dapat dibuat kesimpulan bahwa pendidikan dapat mempengaruhi seseorang juga perilaku seseorang dalam mengelola informasi baru yang didapat dan pola pikir seseorang terutama dalam memotivasi diri dalam meningkatkan pengetahuan yang ada pada saat proses pengobatan anggota keluarga sehari-hari.

Hasil penelitian hasil uji statistik dengan analisis chi square didapatkan $\rho$ value $=$ 0,528 lebih besar dari $\alpha=0,05$ menunjukkan bahwa tidak ada hubungan antara sumber informasi dengan pengetahuan di Puskesmas Palembang Tahun 2021.

Hal ini sejalan dengan penelitian yang ada yang mengatakan bahwa berdasarkan hasil wawancara beberapa reponden didapatkan bahwa mereka tidak memiliki pengalaman sama sekali dalam merawat pasien stroke. Demikian juga tidak adanya sumber informasi yang pernah mereka dapatkan terkait perawatan pasien stroke, baik dari petugas kesehatan atau perorangan maupun dari media elektronik ataupun cetak dengan hasil penelitian didapatkan ada pengaruh pendidikan kesehatan tentang perawatan pasien stroke di rumah terhadap tingkat pengetahuan keluarga (Yanti et al., 2020; Bakri et al., 2020).

Hasil penelitian Forster et al., (2020) menyebutkan bahwa cara terbaik untuk memberikan informasi kepada pasien stroke masih belum jelas, karena hasilnya menunjukkan tidak ada efek yang konsisten pada pengetahuan dan perilaku kesehatan, meskipun beberapa kebutuhan pasien yang tidak terpenuhi mengenai penyediaan informasi untuk stroke telah dilaporkan. Mengingat sedikitnya jumlah bahan intervensi yang tersedia dan kualitas bahan yang dianalisis seringkali buruk, tidak dapat dibenarkan untuk menyimpulkan bahwa informasi pasien untuk pasien stroke tidak efektif.

Berdasarkan hasil penelitian yang didapat dan teori yang ada dapat disimpulkan bahwa sumber informasi yang diterima baik yang tidak bervariasi maupun bervariasi tidak menjadi permasalahan terutama terhambatnya suatu informasi dalam meningkatkan pengetahuan seseorang serta dapat menjadi permasalahan pada saat menyampaikan informasi atau menerima pengetahuan yang terbaru. 


\section{SIMPULAN}

Gambaran karakteristik demografi pasien stroke di Puskesmas Kota Palembang diketahui bahwa rata-rata umur pada kelompok intervensi sebesar 54,44, umur pada kelompok intervensi terendah adalah 45 dan skor tertinggi adalah 68.

Terdapat perubahan pengetahuan dan dukungan keluarga diketahui sebagian besar keluarga pasien stroke sebelum diberikan pendidikan; metode peer education memberikan pengetahuan cukup baik dan sebagian besar responden sesudah diberikan pendidikan; metode peer education memberikan pengetahuan sangat baik, sebagian besar keluarga pasien stroke sebelum diberikan pendidikan; metode peer education memberikan dukungan keluarga tinggi dan sebagian besar responden pada sesudah diberikan pendidikan; metode peer education memberikan dukungan keluarga tinggi pada kelompok intervensi dan kontrol serta perbedaan pengetahuan dan dukungan keluarga sesudah pemberian pendidikan; peer education pada kelompok intervensi dan kontrol sebagian besar responden pada kelompok intervensi memberikan dukungan keluarga tinggi dan sebagian besar responden pada kelompok kontrol memberikan dukungan keluarga rendah serta sebagian besar responden pada kelompok intervensi memberikan pengetahuan baik dan sebagian besar responden pada kelompok kontrol memberikan pengetahuan kurang.

Ada hubungan karakteristik umur dengan pengetahuan dan dukungan keluarga di Puskesmas Merdeka, Ariodillah, Basuki Rahmat tahun 2021 dan tidak ada hubungan karakteristik antara tingkat pendidikan dengan pengetahuan di Puskesmas Merdeka, Ariodillah, Basuki Rahmat tahun 2021 serta tidak ada hubungan karakteristik antara sumber informasi dengan pengetahuan di Puskesmas Merdeka, Ariodillah, Basuki Rahmat.

\section{SARAN}

\section{Puskesmas}

Diharapkan penelitian ini dapat menjadi referensi untuk Puskesmas dalam memberikan pelayanan terutama dalam menerapkan protokol kesehatan yang dalam hal ini dengan mengurangi interaksi langsung kepada masyarakat yang memiliki riwayat penyakit stroke dan keluarga pendamping dalam melakukan pengobatan.

\section{Perawat}

Diharapkan penelitian ini dapat menjadi tambahan informasi untuk perawat dalam memberikan pelayanan terutama dalam melakukan Pendidikan kesehatan terutama terkait pencegahan COVID 19 pada pasien stroke dan pemberian informasi nutrisi, pengobatan dalam aktifitas pengobatan untuk dapat menggunakan media sosial dalam memberikan pendidikan kesehatan kepada masyarakat yang memiliki riwayat penyakit stroke dan keluarga pendamping dalam melakukan pengobatan.

\section{Klien}

Diharapkan dapat setelah diberikan pendidikan kesehatan; peer education masyarakat terkhususnya klien dengan riwayat stroke dapat menerapkan cara pencegahan COVID 19 yang telah diberikan dengan selalu memakai masker dan menjaga jarak baik saat di rumah atau saat bertemu dengan orang lain. 


\section{Keluarga}

Diharapkan keluarga pendamping dapat memberikan pemahaman dan menerapkan informasi yang telah didapatkan selama penelitian ini dalam aktifitas sehari-hari terutama saat menjadi pendamping pasien stroke seperti mencuci tangan saat akan dan sesudah bersentuhan lingkungan sekitar, selalu membawa hand sanitizer dan masker, serta selalu mandi setelah kontak dengan lingkungan sekitar.

\section{Keilmuan}

Diharapkan dapat menjadi referensi informasi tambahan untuk peneliti selanjutnya dalam memberikan pendidikan kesehatan; peer education terhadap pengetahuan dan dukungan keluarga pasien stroke pada masa pandemi COVID 19 serta dapat dikembangkan dalam bidang peminatan lainnya.

\section{Peneliti Selanjutnya}

Diharapkan untuk dapat dikembangkan dalam peminatan ilmu lainnya seperti ilmu peminatan anak, komunitas dan lainnya berupa penelitian berupa penelitian kuantitatif untuk menggali lebih dalam mengenai pengetahuan dan dukungan kelurga pada pasien stroke dalam pencegahan covid 19.

\section{DAFTAR PUSTAKA}

Ayuni, S., Auliani, F. D., \& Zuheri, Z. (2021). Hubungan Riwayat Hipertensi dengan Kejadian Stroke Ischemic di Rumah Sakit Umum Daerah Meuraxa Kota Banda Aceh. Jurnal Ilmu Kedokteran dan Kesehatan, 8(1), 34-40. http://ejurnalmalahayati.ac.id/index.php/kesehatan/article/view/3588

Bakri, A., Irwandy, F., \& Linggi, E. B. (2020). Pengaruh Pendidikan Kesehatan tentang Perawatan Pasien Stroke di Rumah terhadap Tingkat Pengetahuan Keluarga Jurnal Ilmiah Kesehatan Sandi Husada. 11(1), 372-378. https://doi.org/10.35816/jiskh.v10i2.299

Chang, D., Xu, H., Rebaza, A., Sharma, L., \& Cruz, C. S. Dela. (2020). Correspondence Workers From Subclinical Coronavirus Infection. The Lancet Respiratory, 2600(20), 2001468. https://doi.org/10.1016/S2213-2600(20)30066-7

Dinas Kesehatan Sumatera Selatan. (2020). Jumlah 10 Penyakit Terbanyak pada Pralansia dan Lansia Dinas Kesehatan Provinsi Sumatera Selatan Tahun 2020. https://dinkes.sumselprov.go.id/

Ellul, M. A., Benjamin, L., Singh, B., Lant, S., Michael, B. D., Easton, A., Kneen, R., Defres, S., Sejvar, J., \& Solomon, T. (2020). Neurological Associations of COVID19. In The Lancet Neurology, 19(9), 767-783. https://doi.org/10.1016/S14744422(20)30221-0

Forster, A., Ozer, S., Crocker, T. F., House, A., Hewison, J., Roberts, E., Dickerson, J., Carter, G., Hulme, C., Fay, M., Richardson, G., Wright, A., McKevitt, C., McEachan, R., Foy, R., Barnard, L., Moreau, L., Prashar, A., Clarke, D., \& Farrin, A. (2021). Longer-Term Health and Social Care Strategies for Stroke Survivors and Their Carers: the Lots2care Research Programme Including Cluster Feasibility RCT. Programme Grants for Applied Research, 9(3), 1-268. https://doi.org/10.3310/pgfar09030 
Hendayani, W. L., \& Sari, D. M. (2019). Pengaruh Dukungan Keluarga terhadap Konsep Diri Pasien Stroke yang Mengalami Kelumpuhan di Poli Klinik Saraf Rumah Sakit Stroke Nasional Bukittinggi Tahun 2018. Jurnal Kesehatan Medika Saintika, 10(1), 85. https://doi.org/10.30633/jkms.v10i1.312

Iadecola, C., Anrather, J., \& Kamel, H. (2020). Effects of COVID-19 on the Nervous System. Cell, 183(1), 16-27.e1. https://doi.org/10.1016/j.cell.2020.08.028

Komalasari, T. (2019). Pengaruh Edukasi dengan Metode Peer Group terhadap Perubahan Pengetahuan, Sikap dan Tekanan Darah pada Lansia di Uptd Puskesmas Sukahaji Kabupaten Majalengka. Universitas Muhammadiyah Jakarta. https://media.neliti.com/media/publications/330500-pengaruh-edukasi-denganmetode-peer-grou-c78c01dd.htm

Kosasih, C. E., Solehati, T., \& Purba, C. I. (2018). Pengaruh Edukasi Kesehatan terhadap Pengetahuan Pasien Stroke dan Keluarga: Peran, Dukungan, dan Persiapan Perawatan Pasien Stroke di Rumah. Media Kesehatan Politeknik Kesehatan Makassar, 13(2), 8. https://doi.org/10.32382/medkes.v13i2.662

Li, X., Geng, M., Peng, Y., Meng, L., \& Lu, S. (2020). Molecular Immune Pathogenesis and Diagnosis of COVID-19. Journal of Pharmaceutical Analysis, 10(2), 102-108. https://doi.org/10.1016/j.jpha.2020.03.001

Lodigiani, C., Iapichino, G., Carenzo, L., Cecconi, M., Ferrazzi, P., Sebastian, T., Kucher, N., Studt, J. D., Sacco, C., Alexia, B., Sandri, M. T., \& Barco, S. (2020). Venous and Arterial Thromboembolic Complications in COVID-19 Patients Admitted to an Academic Hospital in Milan, Italy. Thrombosis Research, 191, 9-14. https://doi.org/10.1016/j.thromres.2020.04.024

Mao, L., Jin, H., \& Wang, M. (2020). Neurologic Manifestations of Hospitalized Patients With Coronavirus Disease 2019 in Wuhan, China. JAMA Neurology, 77(6), 683690. https://jamanetwork.com/journals/jamaneurology/fullarticle/2764549

Merkler, A. E., Parikh, N. S., Mir, S., Gupta, A., Kamel, H., Lin, E., Lantos, J., Schenck, E. J., Goyal, P., Bruce, S. S., Kahan, J., Lansdale, K. N., Lemoss, N. M., Murthy, S. B., Stieg, P. E., Fink, M. E., Iadecola, C., Segal, A. Z., Cusick, M., ... Navi, B. B. (2020). Risk of Ischemic Stroke in Patients with Coronavirus Disease 2019 (COVID-19) vs Patients with Influenza. JAMA Neurology, 77(11), 1366-1372. https://doi.org/10.1001/jamaneurol.2020.2730

Oxley, T. J., Mocco, J., Majidi, S., Kellner, C. P., Shoirah, H., Singh, I. P., De Leacy, R. A., Shigematsu, T., Ladner, T. R., Yaeger, K. A., Skliut, M., Weinberger, J., Dangayach, N. S., Bederson, J. B., Tuhrim, S., \& Fifi, J. T. (2020). Large-Vessel Stroke as a Presenting Feature of Covid-19 in the Young. New England Journal of Medicine, 382(20), e60. https://doi.org/10.1056/nejmc2009787

Pustikasari, A., \& Restiana, R. (2019). Dukungan Keluarga terhadap Motivasi Lanjut Usia dalam Meningkatkan Produktifitas Hidup Melalui Senam Lansia. Jurnal Ilmiah Kesehatan, 11(2), 153-160. DOI: 10.37012/jik.v11i2.92

Wang, C., Chao, J., Wang, M., Yang, Y., Chien, C., Lai, W., Yang, Y., Chang, Y., Chou, C., \& Kao, C. (2020). Care for Patients with Stroke During the COVID-19 Pandemic: Physical Therapy and Rehabilitation Suggestions for Preventing Secondary Stroke. Journal of Stroke and Cerebrovascular Diseases, 29(00), 1-6. https://doi.org/10.1016/j.jstrokecerebrovasdis.2020.105182 
Yaghi, S., Ishida, K., Torres, J., Mac Grory, B., Raz, E., Humbert, K., Henninger, N., Trivedi, T., Lillemoe, K., Alam, S., Sanger, M., Kim, S., Scher, E., Dehkharghani, S., Wachs, M., Tanweer, O., Volpicelli, F., Bosworth, B., Lord, A., \& Frontera, J. (2020). SARS-CoV-2 and Stroke in a New York Healthcare System. Stroke, 51(7), 2002-2011. https://doi.org/10.1161/STROKEAHA.120.030335

Yanti, N. P. E. D., Nugraha, I. M. A. D. P., Wisnawa, G. A., Agustina, N. P. D., \& Diantari, N. P. A. (2020). Gambaran Pengetahuan Masyarakat tentang COVID-19 dan Perilaku Masyarakat di Masa Pandemi COVID-19. Keperawatan Jiwa, 8(3), 491-504. https://jurnal.unimus.ac.id/index.php/JKJ/article/download/6173/pdf

Zhao, J., Wang, Y., \& Fisher, M. (2020). Slower Recovery of Outpatient Clinics Than Inpatient Services for Stroke and Other Neurological Diseases After COVID-19 Pandemic. CNS Neuroscience and Therapeutics, 26(12), 1322-1326. https://doi.org/10.1111/cns.13459 